\title{
THE PROBLEM OF LOGICAL FORM: WITTGENSTEIN AND LEIBNIZ*
}

\begin{abstract}
The article is an attempt at explaining the category of logical form used by Ludwig Wittgenstein in his Tractatus logico-philosophicus by using concepts from Gottfried Wilhelm Leibniz's The Monadology. There are many similarities and analogies between those works, and the key concept for them is the category of the inner and acknowledged importance of consideration based on basic categories of thinking about the world. The Leibnizian account allows for a broader look at Wittgenstein's analysis of the relation between propositions and facts, between language and the world. Using the Hanoverian philosopher's terminology allows for the demonstration of the ambivalence of the concept of logical form in the philosophy of Wittgenstein and also the metaphysical nature of his first book.
\end{abstract}

Keywords: logical form; representation; isomorphism; monadology; Ludwig Wittgenstein; Gottfried Wilhelm Leibniz

1. Introduction. 2. Problem. 3. The Monadology by Leibniz and the Tractatus: similarities.

4. The internal and the monad. 5. The law of the series. 6. Proposition and the monad.

7. The concept of expression. 8. Conclusions.

\section{INTRODUCTION}

There is no clear consensus among commentators as to the interpretation of the concept of logical form used by Ludwig Wittgenstein in his Tractatus logico-philosophicus (TLP). However, it is doubtlessly the central concept of the doctrine in the Tractatian doctrine. It seems that the interpretation of the entire work depends on the interpretation of this concept. This paper is an attempt to decode what

* This article was originally published in Polish as: M. Piekarski, Problem formy logicznej: Wittgenstein a Leibniz, Studia Philosophiae Christianae 51(2015)1, 99-121. The translation of the article into English was financed by the Ministry of Science and Higher Education of the Republic of Poland as part of the activities promoting science - Decision No. 676/P-DUN/2019 of 2 April 2019. Translation made by GROY Translations. 
Wittgenstein said about logical form from a perspective of Gottfried Wilhelm Leibniz's monadology in order to better understand and explain this concept. The Leibnizian perspective allows a more complete formulation of this issue. The thought of this philosopher had a radical impact on the first book of Wittgenstein. The case of logical form is the best example of it, which will be justified in this article.

\section{PROBLEM}

Thesis 4.125 of the Tractatus states that the relationship between objects, or atomic facts "expresses itself in language by an internal relation between the propositions presenting them". It is on this statement that the entire theory of meaning and ontology in the Tractatus is based. What occurs between objects, what is an occurrence in the world, finds its expression in a proposition. What did Wittgenstein mean? It seems that the triad "name/proposition/language" has a structure analogical to "object/atomic fact/the world". The structures of language and the world are similar, it can even be assumed that they are identical, but this fact alone still does not justify ascertaining the existence of any relation of correspondence or identity between them, as Wittgenstein did. Such an assertion would require proving that there is some necessary basis on which one structure relates to another. The empirical fact of speaking about something, i.e. the relation of expressions of significant nature to some objects which are designated by them, does not provide such a basis. The very possibility of ascertaining this relation is another issue.

To understand Wittgenstein's position, attention should be paid to the issue of the tautological character of logical propositions and what they show. The philosopher argues that in the propositions of logic, which are tautologies, essential properties of language and the world are shown. Thus: a tautology shows a certain necessary combination of signs. Necessary - Wittgenstein's reasoning was similar to Leibniz's - means: true in every possible world. Something which would be necessary only in one world, for example in the one which is here and now, does not deserve to be called a necessity. Necessity is closely re- 
lated to possibility ${ }^{1}$. It does not have to occur but it is always necessary as a type of potentiality. This was aptly formulated by Bogusław Wolniewicz in his foreword to the Tractatus logico-philosophicus: "One is therefore allowed to say that something is real by accident, but one is not allowed to say that it is possible by accident"2. This is what tautological connections point to. Connections of propositions in a tautology are necessary since a tautology is a proposition that is always true, hence the fact which is shown by them cannot be merely logical or empirical, but it has to be the "transcendental fact" itself, a necessary fact pertaining to both the world and language. Indeed, a tautology shows the essential properties of language and the world. Otherwise, it wouldn't have the character of necessity.

Discovering the transcendental concept of tautology, Wittgenstein justified the existence of the necessary connection between language and the world, a proposition and its referent. Each logical "resolution" is at the same time a semantic and metaphysical "resolution". The entire connection between signs and things signified was described by Wittgenstein as a representation which is of an isomorphic nature. The concept, derived from set theory, was most probably adopted from Russell and given a transcendental character ${ }^{3}$. Isomorphism is closely connected with the concept of logical form. Russell distinguished grammatical form of a proposition from its logical form, giving the latter a fundamental status. The conventional grammatical form has a subject-predicate structure, which allows assigning certain qualities

1 Leibniz put it simply: if there is reality in essences or possibles (...) this reality must be grounded in something existent and actual, and consequently, it must be grounded in the existence of the necessary being.(G. W. Leibniz, Philosophical Essays, trans. R. Ariew, D. Garber, Indianapolis: Hackett, 1989, 218).

2 B. Wolniewicz, O Traktacie, in: L. Wittgenstein, Tractatus logico-philosophicus, transl. B. Wolniewicz, Warszawa 2004, XXXI.

3 This is about the isomorphism of language and the World. "Two sets with a structure are considered as equivalent to the structure under consideration if there is a bijective [invertible - M.P.] morphism for which the inverse function is also a morphism). In this case we speak of isomorphism, and we call the corresponding sets with structure isomorphic sets" (Atlas matematyki, eds. F. Reinhardt, H. Soeder, transl. Ł. Wiechecki, Warszawa 2005, 41). 
to certain things ${ }^{4}$. Logical form, on the other hand, is a "deep" structure and it actually shows in what way constituents of a proposition, thoughts or facts are connected 5 . According to Russell, the purpose of philosophy is to carry out a logical analysis of propositions, and then to discover and investigate their logical forms $s^{6}$.

Wittgenstein disagreed with Russell on the significance of the study of logical form and, what is more important, he did not share the belief that logical form pertains to any semantic or empirical content ${ }^{7}$. Logical form is a relation constituting all possible connections, references, representations. If it did not exist, users of language would be destined to the randomness of signs, the inadequacy of descriptions, incompleteness of meanings. It guarantees that what is said pictures what occurs, what is actual ${ }^{8}$. Thesis 2.18 summarises this reasoning in the following way: "What every picture, of whatever form, must have in common with reality in order to be able to represent it at all - rightly or falsely - is the logical form, that is, the form of reality". There is no doubt that the connection between language and the world is of a logical, or, in other words, of a structural character. Logical form is precisely the expression of the existence of identical structures.

At this point, we arrive at the essential question about Wittgenstein's structuralism. Namely - what is the character of a logical form? Is it the

4 B. Russell, Our knowledge of the external world: as a field for scientific method in philosophy, Routledge, London and New York 2009.

5 H.J. Glock, A Wittgenstein Dictionary, Wiley-Blackwell, New Jersey, 1996, 203.

6 Russell says that "In every proposition and in every inference there is, besides the particular subject-matter concerned, a certain form, a way in which the constituents of the proposition or inference are put together (....) It is obvious that the knowledge of logical forms is something quite different from knowledge of existing things" (B. Russell, Our knowledge of the external world: as a field for scientific method in philosophy, Routledge 2009, 34).

7 It would take a separate study to discuss Wittgenstein's reliance on Russell. There is no place to deliberate upon it here. Those who are interested in it are referred to, i.a. The False Prison: A Study of the Development of Wittgenstein's Philosophy by David Pears, Oxford 1987.

8 The concept of picturing, which is immensely important in Wittgenstein's discourse, shall be discussed in further deliberations. 
thing which is represented, or is it a way of representation? Or, in other words: is it the thing projected, it the method of projection itself?

The first possibility was discussed by Erik Stenius in his classic work Wittgenstein's Tractatus. A Critical Exposition of its Main Lines of Thought. Let us assume, as he did, that there are two fields $-F$ and $G$. The categorial structure of both fields is the same. For this reason, between elements of each category $F$ and elements of each category $G$ there is a one to one relation described by Stenius as correspondence. This correspondence is "the key to isomorphism". Knowing this "key" one knows on what principle some elements of field $F$ correspond to, or represent, certain elements of field $G$. The represented form is the sought-after "interpretation key". The represented form is a shared categorial - inner, as Wittgenstein would say - structure of the image and of what it pictures ${ }^{10}$.

The second possibility was indicated by Vincent Descombes when discussing French structuralism: "Structural analysis starts from the structure, that is, from relations, defined in a purely formal way with the use of certain properties of a set of elements whose nature has not been specified; starting from the structure thus given, the analysis shows that a certain cultural content (kinship system, myth) is in it a 'model' or, as it is also called, a 'representation'. What therefore has been proven? No more, and no less than the fact that such content is isomorphic compared to a certain number of other content. The structure is, strictly speaking, what is established in an isomorphism between two sets" [emphasis added - M.P.] ${ }^{11}$.

And then, in a footnote on the same page he states a thing of prominent importance: "Let us translate the elements, relations and operations of set $\mathrm{E}$ to the elements, relations and operations of set $\mathrm{E}$ ': there is an isomorphism between $\mathrm{E}$ and $\mathrm{E}$, if the translation of the result, which was true in $\mathrm{E}$, is also true in $\mathrm{E}$, and if to a false result in

9 This ambiguity was pointed out to me by Andrzej Leder.

10 E. Stenius, Wittgenstein's "Tractatus". A Critical Exposition of its Main Lines of Thought, Oxford 1960, 93-101.

11 V. Descombes, Le Même et l'autre. Quarante-cinq ans de philosophie française (1933-1978), Editions de Minuit, Cambridge 1979, 104-105. 
$\mathrm{E}$ corresponds a false result in $\mathrm{E}^{\prime \prime 12}$. The mathematical origin of this formula is outright evident ${ }^{13}$.

The logical form can be on some occasions understood as the projected content, and on other occasions - as the projection itself. It seems that it was not entirely clear to Wittgenstein how to understand logical form. Sometimes he talked about it as a certain structure (from as "the possibility of the structure", TLP2.033), sometimes as the norm of representation (form as a "representation").

It was as late as in his article Some Remarks on the Logical Form published in 1992 that a thesis is formulated that logical form is a method of projection. It is not so clear in his Tractatus. The reason for this is probably the fact that the concept is still strongly imbued with Russell's metaphysical influences, with their origins dating back to Leibniz's philosophy. Therefore, to find the answer to the question about the character of logical form, we should go back to the deliberations of the Hanoverian philosopher.

\section{THE MONADOLOGY BY LEIBNIZ AND THE TRACTATUS: SIMILARITIES}

It might seem surprising to refer at this point to the thought of the 17th-century philosopher, who was certainly not close to Wittgenstein ${ }^{14}$. Although Wittgenstein's knowledge of Leibniz's thought was insignificant, it will not be an exaggeration if we say that the Tractatus is Leibnizian in its spirit. The essential ideas and concepts in the Tractatus logico-philosophicus have their origins in Leibniz's monadology.

It was probably through Bertrand Russell, who in 1900 wrote a voluminous monograph entitled $A$ Critical Exposition of the Philosophy of Leibniz, that Leibniz's ideas became known to Wittgenstein. Earlier, between 1898 and 1899, Russell delivered lectures about Leibniz in Cambridge ${ }^{15}$. Russell's study of Leibniz made it possible for him to

12 Ibid, 105.

13 Cf. footnote 10 .

14 Wittgenstein's biographer - R. Monk, does not mention his knowledge od Leibniz's writings. There are no references in Wittgenstein's Nachlass either.

15 B. Russell, A Critical Exposition of the Philosophy of Leibniz, London 1900, v. 
move away from Bradley's idealism and at the same time formulate a programme of philosophy founded on the logical analysis of propositions. What did he find in Leibnitz to inspire him to write a book which was "against traditional logic"16?

Leibniz's metaphysics was based on the foundation of logical theory. According to Russell, the entire system proposed by Leibniz was based on the assertion that "all judgements can be reduced to a type attributing some predicate to some subject"17. The concept of the substance itself, as an existent and complete subject ${ }^{18}$, "something what it unifies" ${ }^{\prime \prime}$, according to Russell appeared because of the subject-predicate form of the judgement. This form is "projected" to the universe of what is given, and simultaneously treated as the form of the object-substance-monad ${ }^{20}$. Elzenberg stated that all predicates which can be asserted about the substance (impossibility of interaction, inseparability, indivisibility, pre-established harmony etc.) result from this logical foundation ${ }^{21}$, and the principle of analyticity ("all truths are analytical") is a reformulation of the assertion that "in all trues the predicate is included in the subject". As such, it constitutes "the foundation of Leibniz's system and as if his keynote"22.

16 H. Elzenberg, Z historii filozofii, ed. M. Woroniecki, Kraków 1995, 21.

17 Ibid, 20-21. Elzenberg also pointed to the immense significance of Russell's study of Leibniz's philosophy, proving that the entire 18th and 19th centuries attributed purely historical meaning to him: "the author was showered with flowers, and the system was presented in such a way that, if his reasoning was really as it was presented, it would deserve anything but those flowers" (Ibid, 19).

18 Leibniz defines it as follows: "The nature of an individual substance or of a complete being is to have a notion so complete that it is sufficient to contain and to allow us to deduce from it all the predicates of the subject to which this notion is attributed". G. W. Leibniz, Philosophical Essays, op. cit., 41. [emphasis added - M.P.].

19 M. Heidegger, Pathmarks, ed. W. McNeill, Cambridge University Press, Cambridge 1998, 72.

20 Design in the sense of constructing a certain structure, creating a certain pattern and at the same time as representing or picturing. Both these meanings of the concept of projection appear in the Tractatus doctrine.

$21 \mathrm{H}$. Elzenberg, Z historii filozofii, op. cit., 50-51.

22 Ibid, 55. Elzenberg also showed that Leibniz follows the thought of Aristotle presented in Prior Analytics, taking into account the content of a proposition rather than its scope. By focusing attention on the content, he can formulate the principle of analyticity. See also: 
The metaphysical solutions proposed by Leibniz are based on the form of a subject-predicate judgement. Let us have a closer look at the concept of the substance itself. The definition of substance adopted by Leibniz, together with the principle of analyticity led him to claim that every substance contains all its definitions, i.e. all that can be said about it is included in its concept. To use Wittgenstein's terms, the substance-subject is constituted by internal, formal qualities: such qualities, as to which it is unthinkable that a given object would not possess them (TLP 4.123). For this reason, they constitute the structure of an object. At this point, Wittgenstein's and Leibniz's reasoning significantly converge ${ }^{23}$. Let us attempt to compare the following paragraphs from The Monadolog $y^{24}$ and the Tractatus logico-philosophicus ${ }^{25}$ :

\begin{tabular}{|l|l|}
\hline $\begin{array}{l}\text { 1. The monad, about which we shall speak } \\
\text { here, is nothing other than a simple substance } \\
\text { which enters into compounds, 'simple' mean- } \\
\text { ing 'without parts'. }\end{array}$ & $\begin{array}{l}2.02 . \text { The object is simple. } \\
2.0272 . \text { The configuration of the objects forms } \\
\text { the atomic fact. }\end{array}$ \\
\hline $\begin{array}{l}\text { 2. And there must be simple substances, } \\
\text { because there are compounds; for the com- } \\
\text { pound is nothing but an accumulation or } \\
\text { aggregate of simples. }\end{array}$ & $\begin{array}{l}\text { 2.01 An atomic fact is a combination of objects } \\
\text { (entities, things). }\end{array}$ \\
\hline $\begin{array}{l}\text { 3. Now where there are no parts, neither } \\
\text { extension, nor shape, nor divisibility is possi- } \\
\text { ble. And these monads are the true atoms of } \\
\text { nature and, in a word, the elements of things. }\end{array}$ & $\begin{array}{l}\text { 2.021 Objects form the substance of the world. } \\
\text { Therefore they cannot be compound. }\end{array}$ \\
\hline
\end{tabular}

G. W. Leibniz, Letter to Arnauld, In: Philosophical Papers and Letters, ed. L. E. Loemker, Dordrecht, Springer, 1989, 148-150.

23 By this "convergence" I mean a certain congeniality of solutions adopted by both philosophers, and not that Wittgenstein was a Leibnizian, of which I was accused by a reviewer writing for a certain philosophical periodical. The Leibnizian style of thinking present in all essays by Russell influenced young Wittgenstein. And, on the other hand, many interpreters speak of the influence of Kant to the Tractatus, while according to recent research, Wittgenstein never read Kant's works (this was discussed in Kirchberg (Austria), by Joachim Schulte during the 6th Wittgenstein Summer School in August 2014). He was acquainted with him, like with Leibniz, through Bertrand Russell.

24 G. W. Leibniz, Leibniz's Monadology. A New Translation and Guide, trans. L. Strickland, Edinburgh, 2014.

25 Similarities between Leibniz's philosophy and the doctrine of the Tractatus were indicated by J. Perzanowski in his Teofilozofia Leibniza (cf. J. Perzanowski, Teofilozofia Leibniza, in: G. W. Leibniz, Pisma z teologii mistycznej, trans. M. Frankiewicz, Kraków 1994, 274). 
8. Yet monads must have some qualities [and some changes], otherwise they would not be beings at all [and if simple substances were non-entities, compounds also would be reduced to nothing]. And if simple substances did not differ qualitatively, there would be no way of perceiving any change in things, since what is in the compound can only come from its simple constituents, and if monads were without different qualities they would be indistinguishable from one another, since they do not differ quantitatively either.
2.0233. Two objects of the same logical form are - apart from their external properties - only differentiated from one another in that they are different.

2.02331. Either a thing has properties which no other has, and then one can distinguish it straight away from the others by a description and refer to it; or, on the other hand, there are several things which have the totality of their properties in common, and then it is quite impossible to point to any one of them.

Leaving aside certain differences, the style of inquiries made by both philosophers is very similar. The scheme is as follows: each compound thing (in Leibniz's words - substance, in Wittgenstein's - fact or atomic fact) is constituted by simple, not compound elements (monads and simple objects respectively). These, in turn, are elements of reality and as such necessarily have to be based on what is called by Leibniz "intrinsic denomination" 26 , and by Wittgenstein formal or internal structure ${ }^{27}$. In Leibniz's theory, "diversity is generated by combining many simpler substances, ultimately the simplest ones, into more compound complexes" 28 . In Wittgenstein's case, this thought is expressed in the so-called principle of extensionality (TLP 5), which is a logical rewording of Leibniz's postulate. All this is based, as we have already mentioned, on the metaphysics of what is internal. For there are no pure external, contingent definitions - there must be an internal principle at the foundation of everything. This is Leibniz's main thought, and the doctrine of monads which "have no windows" 29 , and the theory of pre-established harmony are derived from it.

The area that we have indicated still does not explain the necessity of the "language-world" relationship. Both in Leibniz's and Wittgenstein's

26 G. W. Leibniz, Leibniz's Monadology, op. cit., 15.

27 They must be based on necessity, as otherwise they would have to have external empirical - definitions, which at the same time would mean their compound nature.

28 P. Gut, Leibniz: myśl filozoficzna w XVII wieku, Wrocław 2004, 67.

29 G. W. Leibniz, Leibniz's Monadology, op. cit., 15. 
thought, this relation can have the status of a logical possibility, but the possibility is still not a fact, and both philosophers seem to support the thesis about the founding and necessary character of the sign-referent relation. The key concept for both philosophers is that of logical form and, to be more precise, the assumption that logical form is the form of language, but also - what seems more important - a form of the world. It is not significant here that for Leibniz logical form had the form of a subject-predicate judgment, and for Wittgenstein is assumed the form of Frege's function ${ }^{30}$. It seems irrelevant from an ontological perspective. The most important question is how the two philosophers came to the same conclusion, namely the necessary relation between language and the world. The answer seems obvious: they both started from the same assumptions. However, as we have already noted, Wittgenstein's deliberations are not convincing when it comes to explaining the problem of agreement of forms when dealing with two different forms (language and the world), and identical ones at the same time ${ }^{31}$, or in the case of the form itself, when only one "reconciling" form exists ${ }^{32}$.

We are left with two solutions: either we assume that Wittgenstein "dogmatically" believed in the logical relation between language and the world, or we turn to Leibniz hoping that we find the answer to our question there.

\section{THE INTERNAL AND THE MONAD}

Leibniz understood substance as a structure governed by the so-called "intrinsic denomination" ${ }^{3}$. All its significant, and therefore necessary properties, are internal properties, and the internal principle is the principle that governs the substantial structure ${ }^{34}$. What decides about

30 TLP 3.318: "I conceive the proposition - like Frege and Russell - as a function of the expressions contained in it".

31 This is related to Leibniz's principle of identity of indiscernibles.

32 At this point we go back to our initial question about the character of form.

33 G. W. Leibniz, Leibniz's Monadology, op. cit., 15.

34 Ibid, section 15: "The action of the internal principle which brings about the change or passage from one perception to another." 
the substantiality of substance, about its nature, is drive $\mathrm{e}^{35}$, the internal factor, "primum constitutivum of original unification" ${ }^{36}$. A substance in itself is innerness, since "all predicates and events" 37 are included in its definition. Structure constitutes itself and at the same time determines its possibilities. Leibniz called it "Leibniz's rule" (law of the series $)^{38}$. From the "innerness" of the substance follows Leibniz's entire thought called monadology, and the thesis of pre-established harmony. It is worth to have a closer look at it.

Leibniz stated that every substance is governed by drive, i.e. a passage from one perception to another. Drive has a strictly internal character ${ }^{39}$. The substance shall be henceforth called monad. What Leibniz understood as monad, combines all essential meanings of the Greek word monas - "simple", "unity", "the one" ${ }^{40}$. Substance as a unifying individual is a monad by definition, and as such, it is the primary building material for reality, what is constitutive and constituting ${ }^{41}$. Monad as the primary drive is, to use a term from

35 M. Heidegger, Pathmarks, ed. W. McNeill, Cambridge 1998, 74.

$36 \mathrm{Ibid}, 73$.

37 G. W. Leibniz, Philosophical Essays, op. cit., 72-73.

38 The right of the series will be addressed in further considerations

39 G. W. Leibniz, Leibniz's Monadology, op. cit., 16-17. Heidegger claims it's a process of unification, individuation: "What then makes each monad ultimately just this particular monad? How is individuation itself constituted? Recourse to the Creation is only the dogmatic explanation of the origin of what is individuated, and not the clarification of individuation itself. What makes up the latter? The answer to this question must explicate the essence of the monad even further. Obviously individuation must take place in that which basically constitutes the essence of the monad, in drive. What essential character in the structure of drive makes a particular individuation possible and thus grounds the peculiar uniqueness of each monad? To what extent is that which primordially unifies a self-individuating in its very unifying? When we previously set aside the connection with Creation, we did so only inasmuch as it is a dogmatic explanation. Nevertheless, the metaphysical sense expressed in describing the monad as created is its finitude. Considered formally, finitude means restrictedness. To what extent can drive be restricted? If finitude as restrictedness belongs to the essence of drive, then finitude must be defined within the fundamental metaphysical feature of drive. But this fundamental feature is unification, and unification as pre-hending, as surpassing in advance".

40 Ibid, 63.

41 It functions as Wittgenstein's simple object/name of what guarantees the intelligibility of the world and language. Cf. thesis 3.23: "The postulate of the possibility of the sim- 
systems theory, an organisation, autopoietic, self-organising structure, $^{42}$ and in this fact one should seek, according to Leibniz, the organisation of the superstructure which is reality.

Monad as a primary, internal organisation, is governed by the same laws as Wittgenstein's logic. Its equivalent is the grid of properties and internal relations. Leibniz called them a true reality. For this reason, as rightly pointed out by Robert Spaemann, "an indefinite structure of monads lies at the foundations of perceptible reality. On the other hand, the perceptible world is a symbol of the non-perceptible world of monads" ${ }^{43}$. Both realities, henceforth defined as inter- and extra-monadic, are divided by not so much an ontological, as by a transcendental chasm. Why?

We are approaching the line of demarcation between necessity (transcendental logic) and contingency (experience), between the sign and the signified. This line is where sense comes into existence. The necessity alone, without referring to what is external, what normalises, is empty, and the experience alone, without normalising principles, referred to as possibilities, is chaos, whereof one must be silent (TLP 7).

Is it the same in Leibnizian monadology? In terms of content - it is not. Discourses of the two philosophers are different. However, from a formal point of view, from a structural perspective, Leibniz and Wittgenstein are advocates of the same thesis. One has to have a close look at Leibniz's writings to see it. Leibniz might point to a solution of Wittgenstein's aporia.

\section{THE LAW OF THE SERIES}

Monad was defined as unity, the individual that constitutes and is constituted by drive. At this point, one should search for a law which governs the entire autopoietic system. We have already mentioned

ple signs is the postulate of the determinateness of the sense".

42 About autopoietic system, cf. M. Maciejczak, Brentano i Husserl. Pytanie epistemologiczne, Warszawa 2001.

43 R. Spaemann, R. Löw, Cele naturalne: dzieje i ponowne odkrycie myślenia teleologiczneg, transl. A. Półtawski, Warszawa 2008, 131-132. 
about the internal principle, about the being of a monad as a drive, but this is still not an explanation that would satisfy Leibniz. He was rather looking for a law that could be expressed mathematically, that is one that could be formulated in a concrete algebraic equation ${ }^{44}$. This sought-after formula is the law of the series ("Leibniz's rule"), available only in infinite perceptibility which is, according to Leibniz, available only to $\mathrm{God}^{45}$. It is "in its own way an expression of substantial and individual drive" ${ }^{\prime 46}$. It contains in itself all possible relations, including the two most important ones - the relations of consequence and simultaneity which are responsible for the constitution of time and space ${ }^{47}$. The law of the series is a prerequisite for the development of every monad, establishing all its relations in the order of succession and simultaneity. "And as every present state of a simple substance - states Leibniz in Monadology - is naturally a consequence of its preceding state, in such a way that its present state is big with the future. . " ${ }^{48}$. The discovery by Leibniz of these spatial-temporal vectors, constituted by the monadic subject, is one of his greatest merits, and we believe that it was it that has determined to a great extent the development of philosophy starting from Kant, through Husserl, to Heidegger's Being and Time.

Having established the law of the series, Leibniz said: "Therefore, we must not conceive of a vague Adam, that is, a person to whom certain attributes of Adam belong, when we are concerned with deter-

44 S. Cichowicz. Przedmowa, in: G. Leibniz, Korespondencja z Antoine'em Arnauldem, transl. S. Cichowicz, J. Kopania, Warszawa 1998, XXII. P. Gut, Leibniz: myśl filozoficzna w XVII wieku, op. cit., 81-83. "The mathematical equivalent of this idea [i.e. the law of the series - M.P.] is the concept of differentiation" (Ibid, 83).

45 Borges formulated this idea - with clear reference to Leibniz - as follows: "What is infinite intelligence? The reader might ask. There is theologian who would not define it; I prefer to illustrate it. The steps taken by a man from his birth to his death draw, in time, an incomprehensible figure. Divine intelligence immediately deciphers this figure, just as human intelligence would decipher a triangle. It is possible that this figure has its specific role in the picture of the universe" (as cited in: S. Cichowicz. Przedmowa, op. cit., XXII).

46 Ibid, XXII.

47 G. W. Leibniz, Leibniz's Monadology, op. cit., 18.

48 Ibid., 18. 
mining whether all human events follow from his assumption; rather, we must attribute to him a notion so complete that everything that can be attributed to him can be deduced from it" 49 . He then distinguished subject as a person from a subject as the basis for substance. Both of these distinctions disappeared from his thought over time, and substance, monad and subject were considered to be the same. The subject-monad derives its individual history, habitualities and habits from the law of the series, but it is also a vehicle for its future as anticipation, bearing in mind that "this anticipation, however, is no longer an actual possibility of a specific future state of rest, but it is a rule of producing a series of certain states which can be thought of as a functional equation" ${ }^{50}$. All this is already contained in the concept of substance, in its "intrinsic quality".

We are already one step away from "ontological" theses of the Tractatus. Wittgenstein claims: "if I know an object, then I also know all the possibilities of its occurrence in atomic facts. (Every such possibility must lie in the nature of the object).... If a thing can occur in an atomic fact the possibility of that atomic fact must already be prejudged in the thing" [emphasis added - M.P.] (TLP 2.0123, 2.012).

The knowledge of internal properties of an object - its features (as Leibniz says - concept), pertains to its actual and possible positions, configurations, arrangements, establishments, contexts. The logical structure of an object, also known as formal or internal structure, is a logical form, that which is projected by language (assuming the representation of language on the world) or that which projects, determines language (assuming the representation of the world on language).

Wittgenstein, unlike Leibniz, talked about "external" consequences of the constitution of an object, about its configurations in atomic facts, relations to situations and its role in the constitution of the world, what we called the extramonadic sphere (TLP 2.01-2.02). Leibniz talked about what is inter-monadic: about the history, genesis, and internal motion of a monad. The difference is visible, but it is not so significant

49 G. W. Leibniz, Philosophical Essays, op. cit., 72-73.

50 R. Spaemann, R. Löw, Cele naturalne: dzieje i ponowne odkrycie myślenia teleologicznego, op. cit., 130. 
as to prevent the assumptions of the two philosophers from converging into a shared conclusion, namely the thesis about the existence of isomorphism. On what grounds do Leibniz and Wittgenstein accept isomorphism? Why is logic a warranty of the language-world relation?

\section{PROPOSITION AND MONAD}

In thesis 5 , Wittgenstein stated that an elementary proposition is a truth-function of itself. This means that its sense does not depend on the sense of any other proposition (TLP 4.211) The discovery of this fact by Wittgenstein led him to formulate a thesis - rejected later in Some Remarks on Logical Form - concerning the independence of elementary propositions. Each elementary proposition is a fully autonomous and, what is more: necessary semantic unit. Why necessary? For what decides about the content of an elementary proposition are simple names, whose obvious referents are simple objects - necessary elements constituting the entirety of facts - the world. This is the first assumption made by Wittgenstein. The second assumption is associated with the so-calledpostulate of thedeterminatenessofthesenseaccording towhich the logical analysis of each proposition has to have its end (TLP3.23 $)^{51}$. It is a simple name deriving its meaning from an elementary proposition, in accordance with Frege's context principle (TLP 3.3). Both assumptions have a conclusion in common: the assertion of the existence of what is simple, what founds and conditions sense and intelligibility. What is simple is an equivalent of Leibniz's monad.

What is therefore the actual role of what is simple in Wittgenstein's onto-logic? Saying that what is simple constitutes what is compound does not solve the problem, because in the concept of "simpleness" already contains the concept of "compoundness", and vice versa: what is compound refers to what is simple. Unfortunately, most Wittgenstein's discussions in the Tractatus are centred around

51 Wittgenstein, unlike Russell, claimed that logical analysis cannot be infinite. In proposition 3.25 he states that "There is one and only one complete analysis of the proposition". 
this type of grammatical deliberations, as the philosopher himself will note after 1930. However, there are some propositions that shed some light on this problem from another perspective.

Namely, it is typical for an elementary proposition that it expresses, describes part of reality. This is related to Wittgenstein's thesis that "the specification of all true elementary propositions describes the world completely" (TLP 4.26). If one elementary proposition is given, then therewith all elementary propositions are also given (TLP 5.524). Why? This is associated with simple names and simple objects correlated with them that reveal all possible propositions (in the case of names) or facts (in the case of objects) designated by propositions (TLP 2.012, 2.0123, 3.202, 3.22). It is for this reason that an elementary proposition constituted, for example, by two simple names reveals part of the universe, just as the word "rain" reveals its possible uses with such words as "pouring", "wet". It can be therefore said that an elementary proposition is like a piece of a jigsaw puzzle, but one which, once it is used, immediately points to other pieces needed to put the jigsaw puzzle together.

To sum up: the founding order of language and its correlate - the world, is the internal order of structures, relations, grids, lines, constituting places in which a specific intersection, pole, property, or even object appears. The key concept is a structure called logical form by both philosophers. At the very beginning of our discussion of the concept of form and related isomorphism, we asked about the character of the form. Is it a method of projection, a mapping of some structures of one field onto another, or is it rather the very structure which enables isomorphism as the mode of being of language and the world.

We have not answered this question so far, and it is this question that is supposed to point to the answer to the question about isomorphism and the grounds for it. At this point, one should consider in what way what is simple, basic, founding and binding is connected with the problem of isomorphism. Wittgenstein provides the following guidance: an elementary proposition is constituted by simple 
names, it "expresses" 52 (Leibniz's term) part of the world and, because it points to the remaining propositions, which also express the world, such a proposition itself expresses, as it were, the entire world. It can be said that an elementary proposition expresses the world as such.

\section{THE CONCEPT OF EXPRESSION}

The concept of expression is one of the most difficult and troublesome concepts. Leibniz introduced it shortly after the discussion of the nature of monad, in the context of the question about its connection with what it transcendent to it - with extra-monadic reality. It is in the concept of expression that the connection between monad and externality is explained. Monad expresses something. Every substance contains, by virtue of its own concept - eidos, all of its predicates. Along with these predicates we are given at once all possible relationships, configurations, arrangements in which a given monad can be found (cf. TLP 2.012, 2.0123). Leibniz tried to abstract from this concept all ontological consequences and at the same time, he wanted to put it in a conceptual framework, knowing that any intrinsic (structural) quality founds and consolidates each possible external quality $^{53}$. The thesis about intrinsic qualities shows that each monad pictures, reflects, represents, implicates, or finally, expresses, the entire universe. What does it mean that a monad expresses?

"One thing expresses another when there is a constant and regular relation between what can be said about one and the other" 54 . A monad has to contain the principle of expression of the world. The concept of expression (expressio) derives from the concept of perception (perceptio) and it was meant to accurately reflect the sense of Leibniz's perception of a monad.

"Defining perceptio through expressio, through a kind of presentation, Leibniz states in other words that the existence of an item

52 Wittgenstein expressed this thought using the concept of the form of representation.

53 For this reason Elzenberg says that there are no purely external qualities. H. Elzenberg, Z historii filozofii, op. cit., 59.

54 G. W. Leibniz, Letter to Arnauld, op. cit., 339. 
implies the whole universe (as a system of co-existence, as the actual and contingent order of various phenomena); and in fact, he finds it the most strongly in his language, so much his own, as to be idiomatic: in section 13 of Principles of Nature and Grace and section 61 of The Monadology he uses the French word pli ('fold', 'ply', 'plait', 'pleat'); this monadic plis are usually translated as 'folds': 'But a soul can read in itself only that which is there represented distinctly; it cannot all at once unroll everything that is enfolded in it, for its complexity is infinite" "55.

A monad's being is its way of expression ${ }^{56}$. Leibniz claims that each monad as an intrinsically constituted structure which "expresses the universe differently" since "its most individual mission is to be a living mirror of being, a concentrated universe" 57 .

Deleuze explained it as follows: "every individual monad expresses the world. However, this thesis is not sufficiently understandable, as long as it is interpreted in the sense of the belonging of predicates to the expressing monad. Because it is undoubtedly true that the expressed world does not exist outside the monads which express it, and hence it exists in monads as a series of predicates [emphasis added - M.P.] which belong to them. ... The expressed world is composed of differential relations and contiguous peculiarities. It composes the world, to be precise, to the extent to which series which depend on each peculiarity converge with series that depend on other peculiarities: it is this convergence that determines 'mutual existential dependence' as the rule for the synthesis of the world. Where series diverge, another universe begins which is not mutually existentially dependent with the first world" 58 .

55 S. Cichowicz. Przedmowa, op. cit., XXV.

56 Its whole being (Heidegger's Da-Sein) is owing to the ability to express, which is the monadic modus of perception, and at the same time co-existence (Mit-Sein) and Being-in-the-world (In-der-Welt-Sein). It is through expression that a monad transcends itself and reaches the world which is what is expressed.

57 As cited in: S. Cichowicz. Przedmowa, op. cit., XXVII.

58 G. Deleuze, La Logique du sens, Paris 1969, 150-152; as cited in: S. Cichowicz, Przedmowa, op. cit., XXVIII-XXIX. 
A monad reflects the world, expresses it as an expansion "to infinity" of its own predicates, based on the law of the series. The world is a constituted equivalent of a monad, a projected structure resulting from the intersection of one series of predicates with other series. The workings of a monad, its expressibility, consist in a transcendental synthesis connecting some representations with others.

A proposition represents a fragment of reality, expresses it through its infinite and continuous references to the whole logical space. Even the simplest proposition, such as "It is raining today", refers to all possible propositions describing the conditions in which rain may fall, the rain has to fall, and in which rain will not fall. A network, grid, the constellation is formed - called by Wittgenstein the logical space in which propositions determine places for facts in logical space (TLP 3.4). "Although a proposition may only determine one place in logical space" - says Wittgenstein - "the whole logical space must already be given by it. The proposition reaches through the whole logical space" (TLP 3.42). Along with the proposition - just like with Leibniz's monad - the entire world is given. A proposition initiates the process of synthesis which culminates in the workings of language as a whole. The main difference between Wittgenstein's and Leibniz's ideas is the fact that the latter demonstrated a dynamic genesis of the synthesis carried out by a monad, claiming that a monad itself is the source of its movement, changes and history. A monad per se is expressing. It is, as Leibniz says, referring to Aristotle's language - an entelechy, a unity whose eidos is determined by telos - the ultimate purpose. In the case of Wittgenstein, we will not find in a proposition the principle of its movement, the source of projection, representation. This principle, unlike in Leibniz's conception, is not purely immanent, a proposition in the philosophy of the Tractatus is something static, as if in the state of potentiality. It needs what in the metaphysics of the Stagirite is called dynamis - a potency ${ }^{59}$,

59 "Potency" means: the source of motion or change which is in something other than the thing changed, or in it qua other". Aristotle, Metaphysics, trans. H. Tredennick, 1019a http:// 
what moves the proposition as a structure. Language, as it is understood by Wittgenstein, does not have in itself what Leibniz calls drive, force, teleology.

\section{CONCLUSIONS}

We have to state it openly that Wittgenstein was a radical continuer of Leibniz's thought. He unintentionally drew the final consequences from Leibniz's theory of innerness, concluding that the entire immanent structure of the world is the structure of language, its logos. Although the Tractatus bears clear signs of transcendentalism, the core of this publication is thoroughly Leibnizian, in both speculative and dogmatic sense. Wittgenstein in continuing Leibniz's ontological deliberations remained to some extent within the realm of traditional metaphysics. Wittgenstein's intention is Kantian, but the philosopher himself does not take full advantage of his achievements and falls into logicism, or even logocentrism ${ }^{60}$.

Logical form encompasses the sign - referent relation, which reveals the structural relation sign - signified. We have asked: is it the structure, or is it what is projected from one structure onto another? The atomic fact, proposition and thought have the same structures meant as certain inner combinations of elements and constituting relations, which at the same time determine all possible combinations with other objects. Due to the identity of these structures, we are given a kind of an "isomorphic triad" determined by thought, language and the world. Intuitively, this triad is as follows: the world is thought about (isomorphism of thought and the world), propositions are formulated about it (isomorphism of language and thought) and it is spoken about (isomorphism of language and the world). And all this is centred in the concept of logical form which is the logical form of language, thought and reality.

www.perseus.tufts.edu/hopper/text?doc=Perseus\%3Atext\%3A1999.01.0052\%3Abook\%3D5\%3Asection\%3D1019a (access 01.05.2021).

$60 \mathrm{It}$ is also associated with a failure to reflect on the role of the subject. A discussion of this issue may be too much beyond the scope of this article. 
It seems that logical form is either a "collective form", however strange it may sound, encompassing the logical forms of thought, language and the world respectively, or it is the sum of these three forms, or it is what determines the logical forms of thought, language and the world. Did Wittgenstein clearly point to one of these options? Unable to decide if the form should be a structure or a manner of projection, he was caught up in a kind of dialectic. The form is ambiguous and it is in this ambiguity that its transcendental character lies. Depending on how a question is formulated, the form appears to be either the structure of language and the world or, in the context of a question about the constitution of sense, therefore about the role of thinking - a projection of the structure of language onto the entirety of what in speech is called the world. In the ontic order it is a structure, and in the genetic order a projection or mapping.

Leibniz says that reality has the form of a subject-predicate judgement and that this form determines the way of thinking about the world and the subject. Logical form is in his opinion something pre-existing, God's plan, the way how clockwork operates. Wittgenstein, on the other hand, claims that logical form warrants the possibility of speaking in a meaningful way about the world. Logical form as if warranties the significance of language (TLP 6.124). Thus it is a condition of intelligibility, not a way in which the world is established, as in Leibniz's thought.

\section{BIBLIOGRAPHY}

Aristotle, Metaphysics, trans. H. Tredennick. http://www.perseus.tufts.edu/hopper/text?doc $=$ Perseus\%3Atext\%3A1999.01.0052\%3Abook\%3D5\%3Asection\%3D1019a (access 01.05.2021).

Mathematic Atlas, eds. F. Reinhardt, H. Soeder, transl. Ł. Wiechecki, PWN, Warszawa 2005.

Cichowicz S., Przedmowa, in: G. W. Leibniz, Korespondencja z Antoine’em Arnauldem, transl. S. Cichowicz, J. Kopania, PWN, Warszawa 1998.

Deleuze G., La Logique du sens, Les Edtions de Minuit, Paris 1969.

Descombes V., Le Même et l'autre. Quarante-cinq ans de philosophie française (19331978), Editions de Minuit, Cambridge 1979. 
Elzenberg H., Z historii fllozofii, ed. M. Woroniecki, Znak, Kraków 1995.

Glock H.-J., A Wittgenstein Dictionary, Wiley-Blackwell, New Jersey, 1996.

Gut A., Leibniz: myśl flozoficzna w XVII wieku, FNP, Wrocław 2004.

Heidegger M., Pathmarks, ed. W. McNeill, Cambridge University Press, Cambridge 1998.

Leibniz G. W., Leibniz's Monadology. A New Translation and Guide, trans. L. Strickland, Edinburgh, 2014.

Leibniz G. W., Philosophical Essays, trans. R. Ariew, D. Garber, Indianapolis: Hackett, 1989

Leibniz G.W., Pisma z teologii mistycznej, transl. M. Frankiewicz, Znak, Kraków 1994.

Leibniz G. W., Philosophical Papers and Letters, ed. L. E. Loemker, Dordrecht, Springer, 1989.

Maciejczak M., Brentano i Husserl. Pytanie epistemologiczne, Oficyna Wydawnicza Politechniki Warszawskiej, Warszawa 2001.

Pears D., The False Prison: A Study of the Development of Wittgenstein's Philosophy, Blackwell, Oxford 1987.

Perzanowski J., Teofilozofia Leibniza, in: Idem, Pisma z teologii mistycznej, transl.

M. Frankiewicz, Znak, Kraków 1994.

Russell B., A Critical Exposition of the Philosophy of Leibniz, Routledge, London 1992 2.

Russell B., Our knowledge of the external world: as a field for scientific method in philosophy, Routledge, London and New York 2009.

Spaemann R., Löw R., Cele naturalne: dzieje i ponowne odkrycie myślenia teleologicznego, transl. A. Półtawski, Oficyna Naukowa, Warszawa 2008.

Stenius E., Wittgenstein's "Tractatus". A Critical Exposition of its Main Lines of Thought, Blackwell, Oxford 1960.

Wittgenstein L., Tractatus logico-philosophicus, transl. C. K. Ogden, Dover Publications, New York 1999.

Wolniewicz B., O Traktacie, in: L. Wittgenstein, Tractatus logico-philosophicus, transl. B. Wolniewicz, PWN, Warszawa 2004.

\footnotetext{
Michał Piekarski

Cardinal Stefan Wyszyński University in Warsaw, Institute of Philosophy, Poland

ORCID: https://orcid.org/0000-0002-9482-526X

m.piekarski@uksw.edu.pl
} 